The Journal of Developing Areas

Volume 48

No.4

Spring 2014

\title{
THE IMPACT OF MENA CONFLICTS (THE ARAB SPRING) ON GLOBAL FINANCIAL MARKETS
}

\author{
Mohammad Mahdi Mousavi* \\ The University of Edinburgh, UK \\ Jamal Ouenniche \\ The University of Edinburgh, UK \\ ESC Rennes, Rennes, France
}

\begin{abstract}
It is believed that financial markets are integrated and sensitive to news - including political conflicts in some regions of the world. Furthermore, financial markets seem to react differently to information flows from one region to another. The purpose of this research is to discern the effects of the recent Middle East and North Africa (MENA) conflicts - commonly referred to as the Arab Spring - on the volatility of risks and returns of global and regional stock markets as well as Gold and Oil markets. To be more specific, we consider the main uprisings in Tunisia, Egypt, Libya and Yemen and their impact on financial markets - as measured by the volatility of their risks and returns. In sum, we cluster 53 stock markets into 6 regions; namely, developed, developing, MENA, Asia, Europe, and Latin America countries, and use TGARCH to assess the reaction of these regions to each uprising event independently. In addition, we use GARCH-M to assess the reaction of these regions stock markets as well as Gold and Oil markets to the uprisings of MENA as a whole. Our empirical findings suggest that the uprising events of MENA have more impact on the volatility of risks and returns of developed, developing, and Europe regions than MENA itself. In addition, although the results show that the volatility of both risks and returns of both developed and MENA regions are significantly affected by general conflicts in MENA, the volatility of MENA is affected during all intervals and with higher significance level. Furthermore, while MENA uprisings as a whole impact on the volatility of risk of oil (after 5 days) and gold (immediately after entering news) significantly, the returns of these markets are not affected by conflicts.
\end{abstract}

JEL Classifications: G01, G15, F59

Keywords: MENA conflicts, Arab Spring, Volatility, T-GARCH, GARCH-M

Corresponding Author's Email Address: s.m.m.mousavi@ed.ac.uk

\section{INTRODUCTION}

Political conflicts occur in different regions of the world and the empirical finance literature has paid some though limited attention to the effect of geopolitical events on asset market behavior. It would not be an overstatement that one of the most critical areas in the world is the Middle East and North Africa (MENA). In this region are located the essential and primary sources of energy reserves in the world (developed and developing) and of course the region has an unusually high concentration of the major purchasers of commercial and military equipment from developed countries. The political and economic news of this region are likely to be highly influential on the global economy. Political conflicts in this region will have an impact not only on the financial markets of the MENA countries but also on global financial markets.

MENA countries have been experiencing rare political conflicts collectively referred to as "The Arab Spring" - a revolutionary wave of protests, uprisings and demonstrations that have been taking place in the Arab world since December 2010. 
Even though it is clear that the popular unrests are born of a desire for more social, political and economic freedom, the time of uprisings came as a surprise for everyone. Although the main causes of these uprisings are political, their economic roots are unavoidably interlinked. Until now, the revolutions in Tunisia and Egypt resulted in departure of their leaders while a civil war in Libya resulted in Gaddafi's death and changes in government. There have also been demonstrations and uprisings in Syria, Bahrain, Yemen and minor protests in Algeria, Iraq, Jordan, Morocco, Oman, Kuwait, Lebanon, Mauritania, Saudi Arabia, and Sudan. It could be argued that there is potential for similar unrest in other important countries in MENA.

These events provide a convenient natural experimental setting for estimating the impact of unexpected and shock news of conflicts on the volatility of international financial markets and the impact of potential unrests (in other countries in this region) on international financial markets. This study contributes to the literature on the reaction of financial markets to political conflicts by providing evidence on market reactions to the news about the unexpected recent conflicts in MENA (see e.g. Ito and Lee 2005, Nikkinen et al. 2008).

We consider commodity markets (oil and gold) in addition to stock markets, which have been the most commonly examined by previous studies (see e.g. Nikkinen et al. 2008, Schwert 1990, Schwert 1989). Gold and oil markets are affected by war and uprisings. This is because gold is considered as a safe investment in the case of conflicts and oil prices are highly sensitive to unrests in oilsupplying countries. We could argue that some exchanges would be safer for investors due to these conflicts.

The main objective of this research is to evaluate the short-term reaction of the major stock markets to the recent MENA conflicts. The study analyses not only the reactions of the MENA markets to the conflicts but assesses the stock market reactions of developed, developing, Asian, European and Latin American regions to these conflicts. Extending the scope of the study across various global regions and focusing on different groups of markets allow us to investigate whether the impacts of such political shocks are limited only to those 'well integrated' markets or whether their impacts are spilling over into various other regions.

Nikkinen et al. (2008) reports, for example, that the September 11 attacks in New York, USA, had only a minor effect on MENA financial markets as compared to its impact on the rest of the world. We, therefore, seek to investigate whether the effect of the recent MENA unrests displays a contagion effect towards other regions, especially developed countries.

We consider four main political conflicts in the MENA region: the Tunisian revolution which ended with the departure of the President of Tunisia, Ben Ali, on 14 January 2011, the Egyptian unrests that resulted in the departure of the President of Egypt, Mubarak on 11 February 2011, the intervention of coalition forces with NATO support in the Libyan civil war, specifically, the coalition's attack on 19 March 2011 and the Yemeni uprisings that caused Ali-Abdullah Saleh to leave the country on 5 June 2011. We consider these dates as the arrival times of news shocks to markets. The volatilities of returns of 53 stock markets are grouped into 6 main regions (see TABLE 2). The commodity markets for gold and oil are also studied and their returns and volatilities are estimated and compared. A T-GARCH model is estimated to measure the asymmetric reaction of regions stock markets to each of the four main political conflicts in MENA independently. Furthermore, we develop a GARCH-M model to measure the volatility of stock markets of different regions as well as commodity markets to conflicts of MENA as a whole. 
The rest of the paper is organized as follows. The second section describes different types of event news which have been considered in literature and reviews the relevant studies related to the impact of political information on stock markets. Moreover, the alternative methodologies which have been used for this purpose are reported. The third section reports on the data and the methods used in this research. The fourth section reports on the empirical analysis and estimation results. The conclusion comes in the last section.

\section{LITRATURE REVIEW}

The origin of day-to-day volatility is not fully determined and a large portion of the variation in prices is unexplainable. It appears that identifiable news events do not always drive much of the observed volatility of prices (e.g. Cutler et al. 1998, Roll 1989). The news events could originate from different fields, but empirical evidence points to political and economic events having large impacts on financial markets (Chan et al. 2001).

In the case of economic news the primary focus is on the effect of macroeconomic news releases such as PPI, GDP and unemployment rate (see Rangel 2010, Chuliá et al. 2010, Cutler et al. 1998, Jones et al. 1998, McQueen and Roley 1993, Ederington and Lee 1995) as well as money supply announcement (see Hardouvelis 1988, Pearce and Roley 1985, Cornell 1983) on stock markets prices. While the reaction of stock markets to economic news is empirically relatively weak and mixed, the evidence of reaction from bond markets is more affirmative (see Balduzzi et al. 2001, Harvey and Huang 1993, Hardouvelis 1988, McQueen and Roley 1993, Cornell 1983, Urich and Wachtel 1981, Grossman 1981). Indeed most studies in this area have considered stock, bond and foreign exchange markets separately, but few have examined all markets jointly (see Andersen et al. 2005).

The news about political conflicts (e.g. uprisings, wars, terrorist attacks) has both real and delusional effects on financial markets. On one hand, some intense conflicts such as wars and terrorist attacks on business centers and infrastructures could change the expected future cash flows, which change in expectations will result in a change in current prices of assets directly. On the other hand, conflicts could inject a sudden shock to financial markets which affect prices and returns by increasing the prevailing uncertainty.

The literature studying the impact of different political conflicts (e.g. parliament and presidential elections, uprisings, civil wars) on the asset markets including currency, stock, bond, commodity and future markets is vast. Table 1 represents some of the most prominent studies related to the impact of political conflicts on financial markets.

Most of related empirical approaches have used two general approaches for examining the effect of conflicts on different asset markets. The first approach is an event study (MacKinlay 1997) which has been implemented in a large variety of studies (see e.g. Abadie and Gardeazabal 2001, Guidolin and La Ferrara 2006, Chen and Siems 2004, Guidolin and La Ferrara 2005, Rigobon and Sack 2005, Wolfers and Zitzewitz 2009) to measure the effects of an economic event on the value of firms.

The second general approach implements GARCH family models for examining the effects of political conflicts on the volatility of asset markets. Nikkinen et al. (2006) and (2008), Flannery and Protopapadakis (2002) and Jones et al. (1998) use a simple GARCH $(1,1)$ model for this purpose. Engle et al. (1987) and French et al. (1995) use the GARCH-M to model financial assets. Also Wei et 
al. (1995) use the GARCH-M model to estimate the impact of volatility and price change on developed and emerging markets.

\section{TABLE 1. OVERVIW OF RELATED STUDIES ABOUT POLITICAL INFORMATION ON STOCK MARKETS}

$\begin{array}{llll}\begin{array}{l}\text { Market / News } \\ \text { Stock/3 main } \\ \text { political issues }\end{array} & \begin{array}{l}\text { Study } \\ \text { (Yue-cheong } \\ \text { and Cjw } \\ \text { 1996) }\end{array} & \begin{array}{l}\text { Data and relations } \\ \text { 1989-1993, daily, } \\ \text { weekly and quarterly } \\ \text { Hong Kong Stock } \\ \text { market Index }\end{array} & \begin{array}{l}\text { Main Results } \\ \text { Political news increases the } \\ \text { stock volatility of shares and } \\ \text { that good (bad) political news } \\ \text { is correlated with positive } \\ \text { (negative) returns for the Hang } \\ \text { Kong Index. }\end{array} \\ \begin{array}{l}\text { Stock/Cease } \\ \text { fire } \\ \text { announcement }\end{array} & \begin{array}{l}\text { (Abadie and } \\ \text { Gardeazabal }\end{array} & \begin{array}{l}\text { 1998 and 1999, daily } \\ \text { 2001) }\end{array} & \begin{array}{l}\text { The stocks on the firms which } \\ \text { sere active in the Basques } \\ \text { have a positive reaction to the } \\ \text { cease-fire announcement by } \\ \text { ETA. }\end{array}\end{array}$

$\begin{array}{ll}\text { Stock/ } & \text { (Abadie and } \\ \text { Political } & \text { Gardeazabal } \\ \text { conflict } & \text { 2001) }\end{array}$

1998-2000, 14 Basque Only the stocks on the firms stocks and 59 nonBasque stocks which were active in the Basques have a positive reaction to the cease-fire announcement.

Stock/ (Chen and

1915-2002, DJIA, 14

Political Siems 2004)

military/ terrorist attacks, daily conflict abnormal return during $[0,10]$

U.S. capital markets today appear to be more resilient and are quicker to absorb news of terrorist attacks and military invasions/ U.S. market resilience can probability be partially explained by a banking/financial sector that provides adequate liquidity to promote market stability and squelch panic.

Stock, Gold, (Rigobon and Jan-Apr (2003), daily Lower equity prices, higher oil Treasury Bills, Sack 2005) prices and rates liquidity premium, currency/ Political conflict Stock,

(Guidolin and 1974-2004, 112 Commodities/ La Ferrara Political 2005) conflict

Stock / Domestic War conflicts, Indices of US, UK, Japan and France, commodities, weakly abnormal returns during [-5,5]

(Guidolin and 1998-2002, daily La Ferrara 2006) abnormal return during $[0,3]$ future prices, lower Treasury yields, fall in dollar and a widening of corporate yield spread are the main consequences of the Iraqi war. Only a fraction of conflicts had a significant effect on most of commodities prices and on stock markets indices.

After ending the war, the prices of Diamond companies showed negative abnormal returns/ Moderate levels of conflict can be beneficial to private firms, while extremely low or high levels of tension reduce their abnormal returns. 


\begin{tabular}{|c|c|c|c|}
\hline Market / News & Study & Data and relations & Main Results \\
\hline $\begin{array}{l}\text { Stock/ } 3 \text { wars } \\
\text { US-led alliance } \\
\text { and Iraq, Ex- } \\
\text { Yugoslavia, } \\
\text { and Israel and } \\
\text { the Palestinians }\end{array}$ & $\begin{array}{l}\text { (Schneider } \\
\text { and Troeger } \\
\text { 2006) }\end{array}$ & $\begin{array}{l}\text { 1990-2000, daily } \\
\text { returns }\end{array}$ & $\begin{array}{l}\text { International crises have } \\
\text { mostly negative impact on } \\
\text { stock markets; most of these } \\
\text { reactions are asymmetrical. }\end{array}$ \\
\hline $\begin{array}{l}\text { Stock/ } \\
\text { September } 11 \\
\text { attack }\end{array}$ & $\begin{array}{l}\text { (Nikkinen et } \\
\text { al. 2008) }\end{array}$ & $\begin{array}{l}2000-2011, \text { several } \\
\text { intervals }[-6,6] \\
\text { months, } 53 \text { stock } \\
\text { markets from } 6 \\
\text { regions }\end{array}$ & $\begin{array}{l}\text { Only developed and European } \\
\text { countries show similar stock } \\
\text { return and volatility reaction } \\
\text { over pre- and to some extent } \\
\text { post-September } 11 \text { attacks/ for } \\
\text { the short-time periods of } 5 \text { and } \\
10 \text { days after the attack, all } \\
\text { regions, but not MENA, } \\
\text { exhibit the same downturn. }\end{array}$ \\
\hline $\begin{array}{l}\text { Oil, stock, } \\
\text { Saddam } \\
\text { Security/ } \\
\text { Political } \\
\text { conflict }\end{array}$ & $\begin{array}{l}\text { (Wolfers and } \\
\text { Zitzewitz } \\
\text { 2009) }\end{array}$ & $\begin{array}{l}\text { Sep } 2002-F e b 2003 \text {, } \\
\text { daily S\&P index }\end{array}$ & $\begin{array}{l}\text { Ex-ante a } 10 \text { percent increase } \\
\text { in the probability of war } \\
\text { decreases the S\&P } 500 \text { by } 1.5 \\
\text { percent and increases spot oil } \\
\text { prices by } \$ 1 \text {. }\end{array}$ \\
\hline Stock/Iraq War & $\begin{array}{l}\text { (Al Refai } \\
2010)\end{array}$ & $\begin{array}{l}\text { 1995-2008, weekly } \\
\text { data of } 11 \text { countries in } \\
\text { the MENA region }\end{array}$ & $\begin{array}{l}\text { Evidences on the effect of Iraq } \\
\text { war in the MENA regions. }\end{array}$ \\
\hline
\end{tabular}

\section{DATA SET AND RESEARCH METHODOLOGY}

The data set for this research is obtained from analyzing international stock markets from six different regions. The region wise analysis approach is a proper one to recognize changes in return and volatility of global stock markets (see e.g., Nikkinen et al. 2006 and 2008).

Since we are interested in estimating the short-term reaction of international asset markets to the 4 main unrests in MENA, the data set comprises stock and commodity markets indices worldwide for the sample period December 2009-June 2010. The global stock markets indices are grouped in 6 different regions (TABLE 2).

\section{TABLE 2. SAMPLE REGIONS AND COUNTRIES}

$\begin{array}{ll}\text { Region } & \text { Country } \\ \text { Developed } & \text { US, Canada, UK, France, Italy, Germany, Spain, Australia, New } \\ & \text { Zealand, Japan, Singapore. } \\ \text { Developing } & \begin{array}{l}\text { Brazil, Mexico, Czech Republic, Russian, Poland, Turkey, Hungry, Chen, } \\ \text { Malaysia, Indonesia, Taiwan, South Africa. }\end{array} \\ \text { MENA } & \begin{array}{l}\text { Iran, Bahrain, Jordan, Lebanon, Oman, Qatar, Kuwait, Saudi Arabia, } \\ \text { Egypt, Morocco, Tunisia. }\end{array} \\ \text { Asia } & \begin{array}{l}\text { India, Pakistan, Philippine, South Korea, Thailand. } \\ \text { Europe }\end{array} \\ \text { Belgium, Denmark, Finland, Greece, Netherlands, Norway, Sweden, } \\ \text { Latin America }\end{array}$


As mentioned before, the aim of this research is to compare the volatility of return (risk) of gold and oil markets as well as capital markets during the political conflicts in MENA. For capturing the returns, we compute the daily returns of all sampled markets. The daily return $\left(R_{t}\right)$ at day $\mathrm{t}$, is measured by $\ln \left(P_{t} / P_{t-1}\right)$, where $P_{t}$ is the asset price at day $t$.

One of the assumptions of this research is that the volatility of asset markets ex-ante and ex-post of time $\mathrm{t}$ are asymmetric. But in GARCH models, the response of volatility to positive and negative shocks is symmetric (Bollersleve, 1986). To capture this asymmetric reaction, we perform T-GARCH model which is developed independently by Zakoian(1994) and Glosten, Jagannathan and Runkle (1994). This model for the variance is;

$$
\sigma_{t}^{2}=v+\alpha \varepsilon_{t-1}^{2}+\gamma I_{t-1} \varepsilon_{t-1}^{2}+\beta \sigma_{t-1}^{2}
$$

where $I_{t-1}=1$ for $\varepsilon_{t-1}<0$ and $I_{t-1}=0$ otherwise. "Good political news" $\left(\varepsilon_{t-1}<0\right)$ has an impact of $\alpha$ on the variance while "Bad political news" has an impact of $\alpha+\gamma$ on the variance. In the case of significant $\gamma$, we conclude asymmetric response to shocks. If $\gamma>0$ a negative shock has a greater impact on the volatility and vice versa. $\beta$ in both cases specifies the persistence of shocks to the conditional variance.

After computing daily returns and volatility for each country, all of them are grouped into six different regions over several periods as mentioned above. For a better comparison between and within regions, we follow Nikkinen et al. (2008) approach through providing different empirical analyses and hypothesis tests which are categorized and described below.

In the beginning we compute some basic descriptive statistics; namely, measures of central tendency (mean and median), volatility (standard deviation) and shape (standardized skewness and standardized kurtosis) for the return and volatility of six regions over three intervals ( 5 days, 10 days, and 1 month).

Next, according to the main research questions, the main hypotheses and proper empirical methods for examining them are provided:

I) Testing the null hypothesis $\left(H_{l}\right)$ that cross-sectional average returns (volatility) of the six regions are equal.

For comparing the averages of returns (volatility) between regions, a one-way analysis of variance (ANOVA) is used under the assumption that the returns are normally distributed. Also, as empirical evidence suggests that daily asset returns are not necessarily normally distributed (Chan, Wei, 1995), the non-parametric test of Kruskal-Wallis $(\mathrm{K}-\mathrm{W})$ is used to test whether there is any significant difference between the medians of returns (volatility) of the six regions in each interval (TABLE 4 and 5).

II) Testing the null hypothesis $\left(\mathrm{H}_{2}\right)$ that, for a given region, the average returns (volatility) before and after an event are equal.

Here we use a t-Test under the assumption that the returns are normally distributed. Furthermore, the non-parametric test of Wilcoxon is used to test whether the medians of returns (volatility) of each given region, before and after an event, are equal (TABLE 6 and 7).

III) Testing the hypothesis $\left(\mathrm{H}_{3}\right)$ that the volatility of MENA return (risk) is generally affected by the arrival of MENA political news more than other regions.

IV) Testing the hypothesis $\left(H_{4-1}\right.$ and $\left.H_{4-2}\right)$ that Oil and Gold markets returns (volatility) are generally affected by the arrival of MENA political news. 
Here we consider the impact of all the four main MENA conflicts on global stock markets (TABLE 8 and 9) and commodities (TABLE 10 and 11). In other words, instead of considering conflicts case by case, the impact of MENA conflicts as a whole is observed and measured.

For this purpose, we define dummy variable series for different intervals after each main conflict in MENA. Here, the main assumption is that good political news would give a positive impact, whereas bad political news would exert a negative impact on the return (volatility) of markets. Thus, we used the Generalized Autoregressive Conditional Heteroscedasticity in Mean (GARCH-M) model (see, Engle et al., 1987) to capture the impact of news on both returns and volatility of markets.

According to Wei et al. (1995), the specification of a traditional form of GARCH-M model is as follow:

$$
\begin{aligned}
& R_{t}=\alpha_{0}+\alpha_{1} h_{t}+\alpha_{2} u_{t-1}+u_{t} \quad \text { where } \sigma_{t-1} \mid \emptyset_{t-1} \sim\left(0, h_{t}\right) \\
& h_{t}=b_{0}+b_{1} u_{t-1}+b_{2} h_{t-1}, \quad b_{0}>0, b_{1} b_{2}>0 \text { and } b_{1}+b_{2}<1
\end{aligned}
$$

where, $R_{t}$ is the return of asset index in period $t$ and $\emptyset_{t}$ is the set of all news available at day $t-1 . u_{t}$ is the error term with a conditionally normally distributed and time varying variance $h_{t}$. We modify the above mentioned GARCH-M model as follow;

$$
\begin{gathered}
R_{t}=\alpha_{0}+\alpha_{1} h_{t}+\alpha_{2} u_{t-1}+\alpha_{3} D N \\
h_{t}=b_{0}+b_{1} u_{t-1}+b_{2} h_{t-1}+b_{3} D E
\end{gathered}
$$

where, $D N$ is the news dummy with threefold possible value; $+1,-1$ and 0 , which represents favorable political news, unfavorable political news and no news respectively. $D E$ is the event dummy with two possible values: 1 when there is political news and zero when there is no news. In addition, dummy variables are defined for different time horizons of zero (for the date of exerting news), 5, 10 and 22 days (for the periods of 5, 10 and 22 days after exerting news, respectively).

To determine the type of news dummies $(D N)$, say favorable $(+1)$ or unfavorable (-1) political news, the weighted average return of a portfolio consists of all stock markets for the day before and after news arrival are compared. The proportion of market value of each region to total market value of all stock markets is assigned as the weight of each region in the final portfolio. A significant positive (negative) change in the portfolio during the day after rather than the day before news arrival is considered as a proxy of favorable (unfavorable) news.

Based on the results in TABLE 3, we consider the ouster of Ben Ali (case of Tunisia) and Hosni Mubarak (Case of Egypt) as well as leaving country by AliAbdullah Saleh (Case of Yemen) as favorable political news and coalition attack on Libya as unfavorable political news in MENA. 
TABLE 3: COMPARISON OF WEIGHTED AVERAGE RETURN OF STOCK MARKETS THE DAY BEFORE AND AFTER NEWS ARRIVAL

This table shows the results of comparison of all stock markets returns the days, Pre- and Post- conflict date, using the parametric t-test and the non-parametric Wilcoxon test. Both statistics along with their significant level are provided. The null hypothesis for the parametric (non-parametric) test is that the mean (median) of pre-date $=$ the mean (median) of post-date, versus the alternative hypothesis of non-equality. A star, dragger and double dragger refer to $1 \%, 5 \%$ and $10 \%$ significance level, respectively. Notice that Positive (negative) t-test means decrease

(increase) in returns mean. However the sign of the z-statistic does not explain increase or decrease in Median.

$\begin{array}{lcccc} & \begin{array}{c}\text { Case of } \\ \text { Tunisia }\end{array} & \begin{array}{c}\text { Case of } \\ \text { Egypt }\end{array} & \begin{array}{c}\text { Case of } \\ \text { Libya }\end{array} & \begin{array}{c}\text { Case of } \\ \text { Yemen }\end{array} \\ \text { Return the day before } & -0.09 \% & -0.79 \% & 0.48 \% & -0.26 \% \\ \text { Return the day after } & 0.14 \% & 0.59 \% & 0.24 \% & -0.01 \% \\ \text { t-statistic } & -2.11^{\ddagger} & -0.489 & 2.31^{*} & -2.13^{\ddagger} \\ \text { K-W statistic } & -1.04 & -0.524 & -0.943 & -1.07\end{array}$

\section{EMPIRICAL ANALYSIS AND RESULTS}

In this section we examine whether MENA conflicts have any effects on the behavior of the global stock markets as well as gold and oil markets. This issue is addressed with five different types of tests mentioned before. For a better presentation, the results are categorized based on the type of market.

\section{Global Stock Markets}

For testing the first hypothesis that the cross-sectional means of returns (volatilities) of the six regions are equal, both the parametric F-test (to examine whether there is any significant difference between the means of returns and volatility of the six regions) and the non- parametric Kruskal-Wallis test (to examine whether there is any significant difference between the medians of returns and volatilities of the six regions) are provided. (TABLE 4 and 5)

\section{TABLE 4. THE (NON-) PARAMETRIC RESULTS OF COMPARISON} BETWEEN THE MEAN RETURNS OF SIX REGIONS

This table presents the results of the two tests of difference among the means, using the parametric t-test (medians, using the non-parametric Kruskal-Wallis test), of each region and reports the results of F-ratio (K-W statistic). A star, dragger and double dragger refer to $1 \%$, $5 \%$ and $10 \%$ significance level, respectively.

\begin{tabular}{cccccccr}
\multicolumn{2}{c}{ Case of Tunisia } & \multicolumn{2}{c}{ Case of Egypt } & \multicolumn{2}{c}{ Case of Libya } & \multicolumn{2}{c}{ Case of Yemen } \\
Pre- & Post- & Pre- & Post- & Pre- & Post- & Pre - & Post- \\
14 Jan & 14 Jan & 11 Feb & 11 Feb & 19 Mar & 19 Mar & 5 Jun & 5Jun
\end{tabular}

Panel A: 5 days

$\begin{array}{lcccccccc}F \text {-statistic } & 1.20 & 1.42 & 8.85^{*} & 3.62^{*} & 3.57^{*} & 11.64^{*} & 3.16^{\dagger} & 9.52^{*} \\ K \text {-W } & (9.20) & (0.27) & (24.74)^{*} & (11.04)^{\dagger} & (8.45) & (11.40)^{\dagger} & (8.32) & (17.93)^{*} \\ \begin{array}{l}\text { Panel B: 10days } \\ \text { F-statistic }\end{array} & 2.29^{\dagger} & 1.22 & 5.49^{*} & 6.63^{*} & 8.86^{*} & 6.63^{*} & 5.13^{*} & 14.21^{*} \\ K \text {-W } & (7.15) & (8.49) & (18.33)^{*} & (11.54)^{\dagger} & (26.06)^{*} & (11.54)^{\dagger} & (15.02)^{\dagger} & (18.33)^{*} \\ \begin{array}{l}\text { Panel C: } 1 \text { Month } \\ \text { F-statistic }\end{array} & 3.03^{\dagger} & 2.71^{\dagger} & 3.49^{*} & 8.05^{*} & 11.98^{*} & 3.59^{*} & 4.89^{*} & 1.62 \\ K \text {-W } & (4.40) & (20.41)^{*} & (20.78)^{*} & (16.12)^{*} & (13.75)^{\dagger} & (10.53)^{\ddagger} & (11.05)^{\dagger} & (12.20)^{\dagger}\end{array}$


As for the case of Tunisia and at the significance level of five percent, the difference between the six means of regions' returns in the periods of pre- and post-1 month as well as pre-10 days are statistically significant. Furthermore the median of regions' returns in the interval of post- 1 month are statistically significantly different. As for uprisings in Egypt, Libya and Yemen, the differences between the means of the returns during all periods in the post- and pre- of all conflicts (except 1 month after Yemen conflict) at the five and ten percent levels of significance are statistically significant. Moreover the results show that there are statistically significant differences among the means and medians during pre- and post- periods of most conflicts.

As mentioned before, it is assumed that T-GARCH model is one alternative for linear structure models in capturing asymmetric and leverage effects. Having looked at TABLE 5, we conclude that there is a significant difference between the means of volatility of all regions during all pre- and post- periods. It is to say that, different regions of the world have different means of volatility pre- and post- of MENA conflicts. In contrast, the medians of volatility are not significantly different. If this is the case, the regions have significantly different means and indifferent medians of volatility which indicates distinctive skewness for regions. However, we cannot draw more conclusions from this table.

\section{TABLE 5. THE (NON-) PARAMETRIC RESULTS OF COMPARISON}

\section{BETWEEN THE MEAN T-GARCH VOLATILITIES OF SIX REGIONS}

This table presents the results of two tests for the difference among T-GARCH volatilities, using the parametric t-test (medians, using the non-parametric Kruskal-Wallis test), of each region and reports the results of F-ratio (K-W statistic). A star, dragger and double dragger refer to $1 \%, 5 \%$ and $10 \%$ significance level, respectively.

\begin{tabular}{cccccccc}
\multicolumn{2}{c}{ Case of Tunisia } & \multicolumn{2}{c}{ Case of Egypt } & \multicolumn{2}{c}{ Case of Libya } & \multicolumn{2}{c}{ Case of Yemen } \\
Pre- & Post- & Pre- & Post- & Pre- & Post- & Pre- & Post- \\
14 Jan & 14 Jan & 11 Feb & 11 Feb & 19 Mar & 19 Mar & 5 Jun & 5Jun
\end{tabular}

Panel A: 5 days

\begin{tabular}{|c|c|c|c|c|c|c|c|c|}
\hline $\begin{array}{l}F \text {-statistic } \\
K-W\end{array}$ & $\begin{array}{l}16.264 * \\
(2.521)\end{array}$ & $\begin{array}{l}12.776^{*} \\
(4.238)\end{array}$ & $\begin{array}{l}14.106^{*} \\
(4.943)\end{array}$ & $\begin{array}{l}12.776^{*} \\
(4.238)\end{array}$ & $\begin{array}{c}3.742 * \\
(9.337)^{\ddagger}\end{array}$ & $\begin{array}{l}12.776^{*} \\
(4.238)\end{array}$ & $\begin{array}{l}8.265^{*} \\
(5.838)\end{array}$ & $\begin{array}{c}3.497^{*} \\
(9.552)^{\ddagger}\end{array}$ \\
\hline \multicolumn{9}{|c|}{ Panel B: 10days } \\
\hline$F$-statistic & $22.131 *$ & $13.514^{*}$ & $22.131 *$ & $13.514^{*}$ & $6.469^{*}$ & $8.682^{*}$ & $11.172 *$ & $3.903^{*}$ \\
\hline$K-W$ & $(2.621)$ & $(5.225)$ & $(2.621)$ & $(5.225)$ & $(2.512)$ & $(6.811)$ & (6.484) & $(11.442)^{\dagger}$ \\
\hline \multicolumn{9}{|c|}{ Panel C: 1 Month } \\
\hline$F$-statistic & $24.234 *$ & $15.858^{*}$ & $24.234 *$ & $15.858^{*}$ & $11.549 *$ & $10.989 *$ & $9.566^{*}$ & $5.035^{*}$ \\
\hline$K-W$ & (4.394) & $(3.596)$ & (4.394) & $(3.596)$ & $(0.76)$ & $(5.155)$ & (4.155) & $(10.804)^{\ddagger}$ \\
\hline
\end{tabular}

For testing the second hypothesis that, for a given region, the average returns (volatility) before and after an event are equal, we use the parametric t-test (tstatistic) and non-parametric Wilcoxon test (z-statistic) for testing the equality of average returns (volatility) of a region pre- and post- an event in MENA.

As seen from panel A of TABLE 6, only the returns of developed and Europe regions show significant decrease over the 5 days post-January 14 at the levels of $1 \%$ and $10 \%$ respectively. Meanwhile for the 10-day period, developed and developing regions exhibit significant decrease in returns. In addition, for a longer period of 1 month, developing and Asia returns decrease significantly. Interestingly, except for the 1 month period at the level of $10 \%$, MENA region returns are not 
affected significantly by Tunisia conflict, although this significant impact could be a result of an overlap with Egypt conflict. From panel B, we can conclude that the case of Egypt is more effective on MENA region, whereas during both post-5 and 10 day periods the return of this region decreases significantly. Likewise, the return of developed region shows a significant decrease over both 10 days and 1 month after February 11. In comparison, developing region exhibits a significant increase over short-term period of 5 days after Mubarak's ouster. At the same time, Europe region shows mixed up results. While over short term periods of 5 and 10 days, there is growth in return of Europe, eventually this region shows significant decline in compliance with Developing and MENA. As seen in panel C, the returns of almost all regions show significant increase after the coalition attack on Libya. MENA region does not exhibit a significant difference in returns between pre- and postMarch 19. The results given from panel D show that Developing, Asia and Europe region show significant decrease in returns over post-10 day period of Yemen conflict. In addition, developed region has a significant increase over post-1 month of this conflict. The rest of the regions are not significantly affected by this conflict.

From TABLE 7 - panel A, it is clear that there are no remarkable changes in the mean volatility of regions after Tunisia conflict. Meanwhile Developing, MENA and Asia have increased in volatility at the level of $10 \%$ over the long term period of 1 month pre- and post-January 14 . The results given from panel B indicate that while the volatility of developed region shows significant increase (at lease at the level of $10 \%$ ) over all intervals, MENA region experiences decrease in volatility. The rest of the regions do not show any significant difference. Panel $\mathrm{C}$ indicates that after the coalition attack on Libya, there is just Europe (at significance level of 1\%) and Developing region (at significance level of 1\%) which have a significant decline in volatility. Meanwhile the volatilities of other regions do not show any significant difference. In the case of panel D (Yemen conflict) there is just developed region which shows significant increase (at the level of 1\%) in volatility after June 5 . The volatility of the rest does not demonstrate remarkable changes.

From the results for testing the second hypothesis, we can conclude that the upheavals in Tunisia that marked the beginning of the Arab spring have had a significant negative impact on the returns of markets in developing and developed regions, though interestingly not on the MENA region markets. More specifically the volatility of returns of markets in the regions is not affected by the actual ouster from power of the President of Tunisia, so it would appear that the markets had correctly anticipated that event, given that the uprising had started.

Egypt has had a bigger effect on global markets across the various regions. The departure of the President of Egypt seems to have been received favorably by the markets of the MENA region - we find increases in the return of stock markets of the region associated with this departure. Meanwhile, the developed region and Europe show significant decreases in return in response to the same event, implying that the markets in these regions saw the same event unfavorably. We find increases in the volatility of both MENA and developed region after Mubarak departed. 


\section{TABLE 6. COMPARISON OF STOCK MARKET RETURNS BETWEEN}

PRE- AND POST- POLITICAL CONFLICTS IN MENA

The table shows the result of comparison of stock markets returns over several intervals, Pre- and Post- conflict date, for 6 different regions, using the parametric t-test and the non-parametric Wilcoxon test. Both statistics along with their significant level are provided. The null hypothesis for the parametric (non-parametric) test is that the mean (median) of pre-date $=$ the mean (median) of post-date, versus the alternative hypothesis of non-equality. A star, dragger and double dragger refer to $1 \%, 5 \%$ and $10 \%$ significance level, respectively. Notice that Positive (negative) t-test means decrease (increase) in returns mean. However the sign of $z$-statistic does not explain increase or decrease in Median.

\section{A: Comparison between pre- and Post- 14 January} Panel A: 5 days Panel B: 10 days Panel C: 1 month

Developed

Developing

MENA

Asia

Europe

Lat. America

$$
\begin{gathered}
7.07 * \\
\text { * }
\end{gathered}
$$

$(-2.937) *$

1.555

$(-1.412)$

(-1.569)

$-0.493$

$(-0.524)$

$(-1.836)$

$(-1.836)$
-0.452

$(-0.135)$

$$
3.189 *
$$

$(-2.667) *$

$2.834^{\dagger}$

$(-2.275)^{\dagger}$

1.528

$(-1.412)$

$(-1.153)$

0.098

$(-0.415)$

$-0.628$

(-0.674)

\begin{abstract}
$-0.230$
$(-0.800)$

$3.187 *$

$(-2.353)^{\dagger}$

1.886 *

$(-1.883)^{*}$

$5.599 *$

$(-2.201)^{\dagger}$

$-0.023$

$(-0.415)$

1.338
\end{abstract}

$\mathrm{C}$ : Comparison between pre- and Post- 19 Marc

Panel A: 5 days Panel B: 10 days Panel C: 1 month

Developed

$$
-5.619 *
$$

$(-2.934) *$

$-5.097 *$

$(-3.059) *$

0.116

$(-0.392)$
-3.917

$(-1.992)$

$-3.016^{\dagger}$

$(-2.310)$

$-1.809$

$(-1.214)$
B: Comparison between pre- and Post- 11 February Panel A: 5 days Panel B: 10 days Panel C: 1 month

$\begin{array}{ccc}-1.788 & 5.617^{*} & 4.868^{*} \\ (-1.512) & (-2.936)^{*} & (-2.845)^{*} \\ -3.583^{*} & -1.544 & -1.699 \\ (-2.824)^{*} & (-1.334) & (-1.412) \\ 2.362^{\dagger} & 2.75^{\dagger} & 0.603 \\ (-2.223)^{\dagger} & (-2.490)^{\dagger} & (-1.647)^{*} \\ -2.307^{*} & -1.835 & -1.716 \\ (-1.782)^{*} & (-1.363) & (-1.363) \\ -0.488 & -2.232^{\ddagger} & 3.908 * \\ (-0.770) & (-1.955)^{\star} & (-2.310)^{\dagger} \\ -2.330^{\ddagger} & -1.599 & -0.191 \\ (-2.023)^{\star} & (-1.483) & (-0.405)\end{array}$

D: Comparison between pre- and Post- 5 June

Panel A: 5 days Panel B: 10 days Panel C: 1 month

1.62 .

$\begin{array}{ccc}(-1.511) & (-0.978) & -3.280 * \\ 0 & 2.646 & -1.490)^{\dagger}\end{array}$

$0.927-2.646^{\dagger}-1.793$

$\begin{array}{lll}(-0.941) & (-2.353)^{\dagger} & (-1.412)\end{array}$

$\begin{array}{lll}-0.726 & -1.414 & -0.551\end{array}$

$(-0.706) \quad(-1.804)^{*} \quad(-0.863)$

$2.469 * 6.808 * 6.379$

$(-1.782) * \quad(-2.201)^{\dagger} \quad(-0.524)$

$1.733-2.846^{\dagger}-1.504$

$(-1.599) \quad(-1.955)^{*} \quad(-1.481)$

$\begin{array}{lll}-0.215 & 0.489 & 0.406\end{array}$

$(-0.135) \quad(-0.674) \quad(-0.674)$ 


\section{TABLE 7. COMPARISON OF STOCK MARKET T-GARCH VOLATILITY BETWEEN}

\section{PRE- AND POST- POLITICAL CONFLICTS IN MENA}

The table shows the result of comparison of T-GARCH Volatility of stock markets over several intervals, Pre- and Post- conflict date, for six different regions, using the parametric t-test and the non-parametric Wilcoxon test. Both statistics along with their significant level are provided. The null hypothesis for the parametric (non-parametric) test is that the mean (median) of pre-date $=$ the mean (median) of postdate, versus the alternative hypothesis of non-equality. A star, dragger and double dragger refer to $1 \%, 5 \%$ and $10 \%$ significance level, respectively. Notice that Positive (negative) t-test means decrease (increase) in volatility mean. However the sign of z-statistic does not explain increase or decrease in Median.

\begin{tabular}{|c|c|c|c|}
\hline & \multicolumn{3}{|c|}{ A: Comparison between pre- and Post- 14 January } \\
\hline & Panel A: 5 days & Panel B: 10 days & Panel C: 1 month \\
\hline \multirow[t]{2}{*}{ Developed } & 1.663 & 0.883 & 1.001 \\
\hline & $(-1.245)$ & $(-0.622)$ & $(-0.711)$ \\
\hline \multirow[t]{2}{*}{ Developing } & 0.095 & -1.055 & $-1.929^{\ddagger}$ \\
\hline & $(-0.471)$ & $(-1.569)$ & $(-1.883)^{*}$ \\
\hline \multirow[t]{2}{*}{ MENA } & 0.836 & -0.191 & $-2.059 \$$ \\
\hline & $(-0.628)$ & $(-0.706)$ & $(-2.510)^{\dagger}$ \\
\hline \multirow[t]{2}{*}{ Asia } & 0.883 & -1.474 & $-2.191^{*}$ \\
\hline & $(-0.524)$ & $(-1.153)$ & $(-1.782)$ \\
\hline \multirow[t]{2}{*}{ Europe } & -1.116 & -1.385 & -1.645 \\
\hline & $(-1.007)$ & $(-1.718)^{\ddagger}$ & $(-2.073)^{\dagger}$ \\
\hline \multirow[t]{4}{*}{ Lat. America } & -0.657 & -1.191 & -1.674 \\
\hline & $(-0.135)$ & $(-1.753)^{\ddagger}$ & $(-2.023)^{\dagger}$ \\
\hline & C: Comparison & etween pre- and $P$ & st- 19 March \\
\hline & Panel A: 5 days & Panel B: 10 days & Panel C: 1 month \\
\hline \multirow[t]{2}{*}{ Developed } & 1.303 & 1.401 & 1.441 \\
\hline & $(-2.934) *$ & $(-2.934) *$ & $(-2.667) *$ \\
\hline \multirow[t]{2}{*}{ Developing } & $1.862^{\ddagger}$ & $1.915 *$ & $1.811^{\ddagger}$ \\
\hline & $(-1.647)^{\ddagger}$ & $(-1.961)^{\dagger}$ & $(-1.647)^{*}$ \\
\hline \multirow[t]{2}{*}{ MENA } & -0.244 & 1.009 & 1.515 \\
\hline & $(-2.118)^{\dagger}$ & $(-2.040)^{\dagger}$ & $(-2.197)^{\dagger}$ \\
\hline \multirow[t]{2}{*}{ Asia } & -0.009 & 0.473 & $2.381 \stackrel{\dagger}{\dagger}$ \\
\hline & $(-0.943)$ & $(-0.524)$ & $(-1.572)$ \\
\hline \multirow[t]{2}{*}{ Europe } & $5.517 *$ & $7.946 *$ & $2.933^{\dagger}$ \\
\hline & $(-2.666) *$ & $(-2.666) *$ & $(-2.310)^{\dagger}$ \\
\hline \multirow[t]{2}{*}{ Lat. America } & 0.403 & -0.359 & -0.661 \\
\hline & $(-0.405)$ & $(-0.405)$ & $(-0.405)$ \\
\hline
\end{tabular}

B: Comparison between pre- and Post- 11 February

Panel A: 5 days Panel B: 10 days Panel C: 1 month

$\begin{array}{cc}\text { Panel B: } 10 \text { days } & \text { Panel } C: 1 \text { month } \\ -2.767^{\dagger} & -2.822^{\dagger}\end{array}$ $-2.822 \dagger$
$(-2.578) *$

$-0.673-(-0.121 \quad-1.484$

$(-1.255) \quad(-0.628) \quad(-1.412)$

$\begin{array}{ccc}2.362^{\dagger} & 1.831^{*} & -1.682\end{array}$

$(-3.056) * \quad(-2.040)^{\dagger} \quad(-1.726)^{\dagger}$

$\begin{array}{lll}-0.089 & 0.127 & -0.309\end{array}$

$(-0.314) \quad(-0.105) \quad(-0.105)$

$\begin{array}{lll}0.144 & -0.888 & 0.103\end{array}$

$(-1.244) \quad(-1.244) \quad(-0.889)$

$\begin{array}{lll}-0.132 & -0.683 & -0.516 \\ (-0.135) & (-0.944) & (-0.674)\end{array}$

Comparison between pre- and Post- 5 Jume

Panel A: 5 days Panel B: 10 days Panel C: 1 mont

$\begin{array}{ccc}-3.752 * & -1.479 & -0.482 \\ (-2.934) * & (-1.511) & (-0.089) \\ 0.171 & 0.207 & 1.968^{\ddagger} \\ (-0.078) & (-0.471) & (-1.883)^{\ddagger} \\ 0.356 & 0.916 & 1.413 \\ (-0.235) & (-0.784) & (-1.569) \\ -0.404 & 0.558 & 0.653 \\ (-0.314) & (-0.105) & (-0.524) \\ -1.813 & -1.975 & -1.650 \\ (-2.666) * & (-2.547)^{\dagger} & (-1.836)^{\ddagger} \\ -0.980 & -0.993 & -0.938 \\ (-0.135) & (-0.405) & (-0.135)\end{array}$


The most intensive conflict in MENA is the coalition attack on Libya on March 11. As evident in the results, the returns of all regions, except MENA, increases significantly after the coalition attack commences in Libya. The return and volatility of MENA are not, however, influenced by the coalition attack on Libya. In contrast, Europe and developing regions show significant increases in the volatility of their stock markets. The Yemeni conflict, which reached its peak on June 5 after Ali-Abdullah Saleh left the country, overlaps with other uprisings in MENA, including Syrian and Bahraini protests. Developing countries, Asia and Europe have experienced significant decreases in returns associated with this event. With the exception of the developed region, however, which shows significant increase in volatility, all regions including MENA display little change in volatility.

For testing the third hypothesis that the volatility of MENA returns (risk) is generally affected by the arrival of MENA political news more than other regions, we used a GARCH-M model for return and volatility of regions. TABLE 8 and 9 exhibit the estimated coefficient and respective standard errors of coefficients of this model.

The results given from panel A of TABLE 8 indicate that for the mean return equation of developed region, coefficient on news dummy, $\alpha_{3}$, has a significant negative value on event day. That is, favorable political news (case of Tunisia, Egypt and Yemen) caused developed region to have a lower return and vice versa for unfavorable news (case of Libya). Also the dummy news is not significant for other intervals. The empirical results of panel B exhibit that none of coefficients of the dummy news are significantly different from zero. Hence, good or bad news of MENA did not have a significant impact on returns of developing region. As seen from panel $\mathrm{C}$, the event day dummy of MENA has a positive significant coefficient which indicates a positive reaction of returns to favorable news and vice versa. Panel D demonstrates that the Asia region dummy news is significant during intervals of 10 days (at significant level of $1 \%$ ) and 1 month (at significant level of 10\%). Both of them are negative which show that favorable news in MENA decreased return of Asia region and vice versa. From panels E and F of table 8, we conclude that MENA conflicts do not significantly impact on the returns of both Europe and Latin America.

TABLE 9 exhibits the estimated GARCH-M model for the volatility of different regions. From panel A, we conclude that either favorable or unfavorable news about MENA have a significant effect on the volatility of developed stock markets on the event day. This effect cannot be captured for other intervals after upheavals. Looking at panel $\mathrm{C}$, the volatility of MENA region is significantly affected by political conflicts over all intervals. Furthermore, as seen from panel $\mathrm{F}$, the significant impact of MENA conflicts on the volatility of Latin America stock markets is remarkable. This impact exists for all intervals excluding 1 month period after struggles. Besides, the volatility of Developing, Asia and Europe are not affected by MENA conflicts. 


\section{TABLE 8. ESTIMATION OF GARCH-M FOR THE RETURN OF DIFFERENT REGIONS}

The table presents the results of estimated coefficients of GARCH-M model $\mathrm{R}_{\mathrm{t}}=\alpha_{0}+\alpha_{1} \mathrm{~h}_{\mathrm{t}}+\alpha_{2} \mathrm{u}_{\mathrm{t}-1}+\alpha_{3} \mathrm{DN}+\varepsilon_{\mathrm{t}}$ for the mean return of stock markets of different regions with different time period dummy variables. Where $R_{t}=$ Close-to-close return in percentage; $\varepsilon_{t}=$ the error term; $h_{t}=$ time-varying conditional variance of $\varepsilon_{t} ; D N$ equals +1 when there is favorable MENA political news and equals -1 when there is unfavorable MENA political news. The standard error of coefficients is provided in prentices. A star, dragger and double dragger refer to $1 \%, 5 \%$ and $10 \%$ significance level, respectively.

Panel A: Developed $\operatorname{Return}\left(\mathbf{R}_{\mathbf{t}}\right) \quad \alpha_{0}$

0.0076 (0.0078)

$-0.0137$

$(0.0152)$

$-0.0141$

(0.0162)

$-0.0153$

Panel C: MENA

$\operatorname{Return}\left(\mathbf{R}_{\mathrm{t}}\right)$

$\begin{array}{ll}\boldsymbol{\alpha}_{0} & \boldsymbol{\alpha}_{1} \\ 0.0031 * & -1.1546 * \\ (0.0006) & (0.2456) \\ 0.0033 * & -1.2341 * \\ (0.0008) & (2980) \\ 0.0031 * & -1.1192 * \\ (0.0008) & (0.3134) \\ 0.0023 * & -0.7741^{\dagger} \\ (0.0008) & (0.3278)\end{array}$

Panel E: Europe

$\operatorname{Return}\left(\mathbf{R}_{\mathbf{t}}\right) \quad \boldsymbol{\alpha}_{\mathbf{b}}$

$\begin{array}{lllll}\boldsymbol{\alpha}_{0} & \alpha_{1} & \alpha_{2} & \alpha_{3} & \text { Period } \\ -0.0010^{\dagger} & 1.4079^{\dagger} & 0.0184 & 0.0002 & \text { Event day } \\ (0.0041) & (0.6033) & (0.0739) & (0.0045) & \\ -0.0093^{\dagger} & 1.3684^{\dagger} & 0.0142 & -0.0009 & \mathbf{5} \text { days } \\ (0.0042) & (0.6187) & (0.0747) & (0.0017) & \\ -0.0086^{\dagger} & 1.2918^{\dagger} & 0.0087 & -0.0016 & \mathbf{1 0} \text { days } \\ (0.0039) & (0.5792) & (0.0752) & (0.0012) & \\ -0.0094^{\dagger} & 1.3818^{\dagger} & 0.0174 & -0.0007 & \mathbf{2 2} \text { days } \\ (0.0042) & (0.6093) & (0.0748) & (0.0008) & \end{array}$

Panel B: Developing

$\operatorname{Return}\left(R_{t}\right) \quad \alpha_{0}$

$\begin{array}{ll}\alpha_{0} & \alpha_{1} \\ -0.0050^{\dagger} & 0.9035^{\dagger} \\ (0.0022) & (0.3576) \\ 0.0067 & -1.088 \\ (0.0063) & (1.1349) \\ -0.0042 & 0.7954 \\ (0.0072) & (1.201) \\ -0.0039 & 0.7496 \\ (0.0050) & (0.8442)\end{array}$

Panel D: Asia

$\operatorname{Return}\left(\mathbf{R}_{\mathbf{t}}\right)$

$\begin{array}{ll}\boldsymbol{\alpha}_{0} & \boldsymbol{\alpha}_{1} \\ 0.0647 & -10 . \\ (0.0770) & (12 .\end{array}$

$(0.0770) \quad(12.8095) \quad(0.0628)$

$\begin{array}{lll}0.0023 & -0.2103 & 0.1692\end{array}$

$\begin{array}{lll}(0.0034) & (0.5672) & (0.0681)\end{array}$

$\begin{array}{lll}0.0029 & -0.2741 & 0.1397\end{array}$ *

$\begin{array}{lll}(0.0027) & (0.4640) & (0.0725)\end{array}$

$\begin{array}{lll}0.0005 & 0.1165 & 0.1708\end{array}$

$\begin{array}{lll}0.0029) & (0.5228) & (0.0673)\end{array}$

Panel F: Latin America

$\operatorname{Return}\left(\mathbf{R}_{\mathrm{t}}\right)$

$\begin{array}{ll}\alpha_{0} & \alpha_{1} \\ -0.0011 & 0.3258 \\ (0.0024) & (0.3869) \\ -0.0019 & 0.4257 \\ (0.0023) & (0.3622) \\ 0.002 & -0.1414 \\ (0.0027) & (0.3747) \\ 0.0035 & -0.3626 \\ (0.0023) & (0.3754)\end{array}$

$\alpha_{2}$

0.1856

(0.0599)

0.1854 *

(0.0620)

$0.1765 *$

(0.0632)

$0.1759 *$

(0.0618)
$-0.0007$

(0.0112)

$-0.0016$

$(0.0017)$

$-0.0018$

(0.0012)

0.0006

(0.0007)

0.0032

$(0.0081)$

$-0.0019$

(0.0024)

-0.0039 *

(0.0012)

$-0.0021^{*}$

(0.0011)

$\alpha_{3}$

0.0039

(0.0033)

0.0002

(0.0016)

$-0.0012$

(0.0013)

$-0.0009$

(0.0011)
Period

Event day

5 days

10 days

22 days

Period

Event day

5 days

10 days

22 days

Period

Event day

5 days

10 days

22 days 


\section{TABLE 9. ESTIMATION OF GARCH-M FOR THE VOLATILITY OF DIFFERENT REGIONS}

The table presents the results of estimated coefficients of GARCH-M model $h_{t}=b_{0}+b_{1} u_{t-1}+b_{2} h_{t-1}+b_{3} D E+\varepsilon_{t}$ for the mean volatility of stock markets of different regions with different time period dummy variables. Where $h_{t}=$ time-varying conditional variance; $\varepsilon_{\mathrm{t}}=$ the error term; $D E$ equals +1 when there is a political news in MENA and equals 0 otherwise. The standard error of coefficients is provided in prentices. A star, dragger and double dragger refer to $1 \%, 5 \%$ and $10 \%$ significance level, respectively.

\section{Panel A: Developed}

Variance $\left(\mathbf{h}_{\mathbf{t}}\right) \quad \mathbf{b}_{0}$

$\begin{array}{ll}\mathbf{b}_{\mathbf{0}} & \mathbf{b}_{\mathbf{1}} \\ 0.0000 & 0.0026 \\ (0.0000) & (0.0179) \\ 0.0000 & 0.0211 \\ (0.0000) & (0.0205) \\ 0.0000 & 0.0216 \\ (0.0000) & (0.0213) \\ 0.0000 & 0.0216 \\ (0.0000) & (0.0203) \\ \end{array}$

Panel C: MENA

$\operatorname{Variance}\left(\mathbf{h}_{\mathbf{t}}\right)$

$\begin{array}{ll}\mathbf{b}_{0} & \mathbf{b}_{\mathbf{1}} \\ 0.0000 * & -0.0508 * \\ (0.0000) & (0.0042) \\ 0.0000 * & -0.0443 * \\ (0.0000) & (0.0056) \\ 0.0000 * & -0.0380 * \\ (0.0000) & (0.0072) \\ 0.0000 * & -0.0237^{\dagger} \\ (0.0000) & (0.0114)\end{array}$

Panel E: Europe

Variance $\left(\mathbf{h}_{\mathbf{t}}\right)$
Panel B: Developing

Variance $\left(h_{t}\right)$

$\begin{array}{lllll}\mathbf{b}_{\mathbf{0}} & \mathbf{b}_{\mathbf{1}} & \mathbf{b}_{\mathbf{2}} & \mathbf{b}_{\mathbf{3}} & \text { Period } \\ 0.0000 & -0.062 & 0.0118 & 0.0000 & \text { Event day } \\ (0.0000) & (0.0404) & (0.7756) & (0.0000) & \\ 0.0000 & -0.0162 * & 1.010 * & 0.0000 & \mathbf{5} \text { days } \\ (0.0000) & (0.0054) & (0.0004) & (0.0000) & \\ 0.0000 & -0.0612 * & 0.0912 & 0.0000 & \mathbf{1 0} \text { days } \\ (0.0000) & (0.0202) & (0.7514) & (0.0000) & \\ 0.0000 & -0.0617 * & 0.564 & 0.0000 & \mathbf{2 2} \text { days } \\ (0.0000) & (0.0071) & (0.6905) & (0.0000) & \\ & & & & \end{array}$

$\mathbf{b}_{2} \quad \mathbf{b}_{3}$

Period

$0.0000 * \quad$ Event day

$(0.0004) \quad(0.0000)$

$0.9995 * 0.0000 *$

$(0.0107) \quad(0.0000)$

$0.9854 * 0.0000 *$

$(0.0105) \quad(0.0000)$

$0.9464 * \quad 0.0000 *$

$(0.0146) \quad(0.0000)$

$\mathbf{b}_{3}$

$0.9070 * \quad 0.0000$

$(0.0448) \quad(0.0000)$

$0.9112 * \quad 0.0000$

$(0.0467) \quad(0.0000)$

$0.9028 * 0.0000$

$(0.0476) \quad(0.0000)$

$0.9067 * 0.0000$

$(0.0467)$

(0.0000)
Panel D: Asia

\section{Variance(ht)} b

$\begin{array}{lll}\mathbf{b}_{\mathbf{0}} & \mathbf{b}_{\mathbf{1}} & \mathbf{b}_{\mathbf{2}}\end{array}$

$\begin{array}{lll}0.0000-0.0065 & 0.4106\end{array}$

$\begin{array}{lll}(0.0000) \quad(0.0105) \quad(1.1815) & 0.06\end{array}$

$0.0000 \quad 0.0608$

$(0.0000) \quad(0.0446)$

$0.0000 \quad 0.1000$

$(0.0000) \quad(0.0563)$

$0.0000 \quad 0.0601$

$(0.0000) \quad(0.0493)$

Panel F: Latin America

$\operatorname{Variance}\left(h_{t}\right) \quad b_{0}$

$\begin{array}{ll}\mathbf{b}_{0} & \mathbf{b}_{1} \\ 0.0000^{\dagger} & 0.1390^{\dagger} \\ (0.0000) & (0.0556) \\ 0.0000^{\ddagger} & 0.1339^{\dagger} \\ (0.0000) & (0.0556) \\ 0.0000^{\ddagger} & 0.1646^{\dagger} \\ (0.0000) & (0.0646) \\ 0.0000^{\ddagger} & 0.1755 * \\ (0.0000) & (0.0638)\end{array}$

5 days

10 days

22 days

Period

5 days

10 days

22 days $b_{3}$

0.0000

(0.0000)

0.0000

(0.0000)

0.0000

(0.0000)

0.0000

(0.0000)

Period

Event day

5 days

10 days

22 days

$0.6894 *$

(0.1226)

$\mathbf{b}_{3}$

Period

$0.0000 *$ Event day

$(0.0000)$

$0.0000^{\dagger} \mathbf{5}$ days

$(0.1238) \quad(0.0000)$

$0.6786 * 0.0000$ *

$(0.1321) \quad(0.0000)$

$(0.0000)$
0.0000

(0.0000) 


\section{Commodity Markets (Oil and Gold)}

In the cases of Oil and Gold markets, we just consider the effect of the whole MENA political news rather than the case by case conflicts. For testing the hypothesis that Oil market return (volatility) is generally affected by the arrival of MENA political news, we estimated the coefficients of GARCH-M model for the return and volatility of oil during struggles interval in MENA (TABLE 10). We conclude that favorable or unfavorable news do not have a significant impact on returns. However the volatility of oil market is influenced by conflicts over periods of post- 5 day of news at the level of five percent.

\section{TABLE 10: ESTIMATION OF GARCH-M FOR OIL}

This table presents the results of estimated coefficients of GARCH-M model for the return and volatility of the Oil market over different time periods dummy variables. The standard error of coefficients is provided in parentheses. A star, dragger and double dragger refer to $1 \%, 5 \%$ and $10 \%$ significance level, respectively.

$$
h_{t}=b_{0}+b_{1} u_{t-1}+b_{2} h_{t-1}+b_{3} D E+\varepsilon_{t} \text { and } R_{t}=\alpha_{0}+\alpha_{1} h_{t}+\alpha_{2} u_{t-1}+\alpha_{3} D N+\varepsilon_{t}
$$

where $\mathrm{h}_{\mathrm{t}}=$ time-varying conditional variance; $\varepsilon_{\mathrm{t}}=$ the error term; $D E$ equals +1 when there is a political news in MENA and equals 0 otherwise; $\mathrm{R}_{\mathrm{t}}=$ Close-to-close return in percentage; and $D N$ equals +1 when there is favorable MENA political news and equals -1 when there is unfavorable MENA political news.

$\begin{array}{llllll}\text { Panel A: Return }\left(\boldsymbol{R}_{t}\right) & \boldsymbol{\alpha}_{\mathbf{0}} & \boldsymbol{\alpha}_{1} & \boldsymbol{\alpha}_{2} & \boldsymbol{\alpha}_{3} & \text { Period } \\ & -0.0012 & 0.2536 & -0.134 & -0.0017 & \text { Event day } \\ & (0.0042) & (0.2687) & (0.0843) & (0.007) & \\ & -0.0024 & 0.3331 & -0.1294 & -0.0004 & \mathbf{5} \text { days } \\ & (0.0043) & (0.2659) & (0.08655) & (0.0025) & \\ & -0.0017 & 0.2897 & -0.0007 & -0.1373 & \mathbf{1 0} \text { days } \\ & (0.004) & (0.254) & (0.0852) & (0.0018) & \\ & -0.0016 & 0.287 & -0.1426^{*} & -0.0005 & \mathbf{2 2} \text { days } \\ & (0.0038) & (0.2508) & (0.0862) & (0.0015) & \\ \text { Panel B: Variance }\left(\boldsymbol{h}_{\boldsymbol{t}}\right) & \mathbf{b}_{\mathbf{0}} & \mathbf{b}_{\mathbf{1}} & \mathbf{b}_{\mathbf{2}} & \mathbf{b}_{\mathbf{3}} & \text { Period } \\ & 0.0000 & 0.3872 & 0.3662 * & -0.0001 & \text { Event day } \\ & (0.0000) & (0.0853) & (0.1543) & (0.0002) & \\ & 0.0001 * & 0.3983 * & 0.3280^{\dagger} & 0.0000 & \mathbf{5} \text { days } \\ & (0.0000) & (0.0906) & (0.1529) & (0.0000) & \\ & 0.0000 * & 0.4188 * & 0.3274^{\dagger} & 0.0000 & \mathbf{1 0} \text { days } \\ & (0.0000) & (0.0895) & (0.1533) & (0.0000) & \\ & 0.0000 * & 0.4280 * & 0.3550^{\dagger} & 0.0000 & \mathbf{2 2} \text { days } \\ & (0.0000) & (0.0971) & (-0.1507) & (0.0000) & \end{array}$


Also for testing the hypothesis that the Gold market return (volatility) is generally affected by the arrival of MENA political news, as seen from TABLE 11, it is clear that the return of the gold market is not affected by conflict news from MENA as well as oil. In comparison to the oil market, good or bad news of MENA impact on the volatility of the gold market on the day of news release at the level of one percent. With a lower significant level of 10 percent, the gold market volatility is affected during the intervals of 1 month after news.

\section{TABLE 11: ESTIMATION OF GARCH-M FOR GOLD}

This table presents the results of estimated coefficients of GARCH-M model for the return and volatility of the Gold market over different time periods dummy variables. The standard error of coefficients is provided in prentices. A star, dragger and double dragger refer to $1 \%, 5 \%$ and $10 \%$ significance level, respectively.

$$
h_{t}=b_{0}+b_{1} u_{t-1}+b_{2} h_{t-1}+b_{3} D E+\varepsilon_{t} \text { and } R_{t}=\alpha_{0}+\alpha_{1} h_{t}+\alpha_{2} u_{t-1}+\alpha_{3} D N+\varepsilon_{t}
$$

where $\mathrm{h}_{\mathrm{t}}=$ time-varying conditional variance; $\varepsilon_{t}=$ the error term; $D E$ equals +1 when there is a political news in MENA and equals 0 otherwise; $\mathrm{R}_{\mathrm{t}}=$ Close-to-close return in percentage; and $D N$ equals +1 when there is favorable MENA political news and equals -1 when there is unfavorable MENA political news.

$\begin{array}{llllll}\text { Panel A: Return }\left(\boldsymbol{R}_{t}\right) & \boldsymbol{\alpha}_{\mathbf{0}} & \boldsymbol{\alpha}_{\mathbf{1}} & \boldsymbol{\alpha}_{\mathbf{2}} & \boldsymbol{\alpha}_{\mathbf{3}} & \text { Period } \\ & 0.0008 & 0.0199 & -0.0499 & -0.0061 & \text { Event day } \\ & (0.0039) & (0.4693) & (0.0673) & (0.0032) & \\ & -0.0063 & 0.8517 & -0.0563 & -0.001 & \mathbf{5} \text { days } \\ & (0.0072) & (0.8431) & (0.0694) & (0.0018) & \\ & -0.0047 & 0.6692 & -0.0507 & -0.0008 & \mathbf{1 0} \text { days } \\ & (0.0069) & (0.8099) & (0.072) & (0.0013) & \\ & -0.7138 & 0.007 & -0.0014 & -0.0505 & \mathbf{2 2} \text { days } \\ & (0.404) & (0.0033) & (0.0009) & (0.516) & \\ \text { Panel B: Variance(ht) }) & \mathbf{b}_{\mathbf{0}} & \mathbf{b}_{\mathbf{1}} & \mathbf{b}_{\mathbf{2}} & \mathbf{b}_{\mathbf{3}} & \text { Period } \\ & 0.0000 * & -0.001 & 0.9025 * & 0.0000 * & \text { Event day } \\ & (0.0000) & (0.0196) & (0.0619) & (0.0000) & \\ & 0.0000 & 0.0048 & 0.7613 * & 0.0000 & \mathbf{5} \text { days } \\ & (0.0000) & (0.0267) & (0.2534) & (0.0000) & \\ & 0.0000 & 0.0014 & -0.0637 & 0.0000 & \mathbf{1 0} \text { days } \\ & (0.0000) & (0.0475) & (1.0731) & (0.0000) & \\ & 0.0001 * & -0.0390 * & -0.9098 * & 0.0000 \ddagger & \mathbf{2 2} \text { days } \\ & (0.0000) & (0.0121) & (0.0385) & (0.0000) & \end{array}$




\section{CONCLUSIONS}

We examined the reaction of 53 stock markets and two commodity markets, oil and gold, to four recent uprisings in the Middle East and North Africa (MENA). We measured and compared the returns and the volatility of returns of the stock markets in these regions both before and after each event. We also investigated the reaction of different regions' markets to these conflicts.

We found a significant difference between pre and post returns and volatility in the six regions for the recent political events in the MENA. The return and volatility of the markets in the MENA region were not significantly affected by uprisings except for the case of the departure of Mubarak. We can see that while the volatility of MENA markets decreases, the returns of the markets of this region increase significantly. On the other hand, after the beginning of the revolutionary movements in the MENA, the returns and volatility of the markets in the developed, developing and Europe experienced increased volatility after each conflict. We conclude that in the case of the revolutions of the MENA they have had more of an impact on the volatility of return of other regions rather than the MENA. In other words, we reject the hypothesis that increased volatility of the markets in the MENA region is associated with the upheavals.

For measuring the effect of the whole MENA conflicts on stock markets of regions, we implemented GARCH-M model, and find out that the return and volatility of both developed and MENA regions are significantly affected by conflicts in MENA. Having more deep concern, we can see that, first of all, the significance level of MENA volatility is more than developed region and secondly, MENA return and volatility is significantly affected during all intervals. As a result, the impact of MENA revolutions as a whole on its stock markets is significantly higher than other regions including developed countries. As a result we can say that MENA is more affected from MENA conflicts as a whole.

In the case of commodity markets we figured out that the return of oil and gold markets were not affected by the recent MENA conflicts. Conversely, the volatilities of these markets show a significant effect from these conflicts. Meanwhile, the gold market shows immediate changes in volatility, but the oil market demonstrates changes after 5 days interval.

\section{ENDNOTES}

*The authors gratefully acknowledge the helpful comments and suggestions of Hardey Thomas from the University of Essex Business School and the anonymous referee.

\section{REFERENCES}

Abadie, A. \& Gardeazabal, J., 'The economic costs of conflict: a case-control study for the Basque country.' 2001, National Bureau of Economic Research Cambridge, Working Paper \#8478.

Al Refai, H. M. ,'The Impact of the Iraq War on the Country Beta of MENA Markets.', 2010, International Journal of Economics and Finance, VOL.3, NO.2, p12. 
Andersen, T. G., Bollerslev, T., Diebold, F. X. \& Vega, C. , 'Real-time price discovery in stock, bond and foreign exchange markets.' , 2005, National Bureau of economic research Cambridge, Working Paper \# 11312.

Balduzzi, P., Elton, E. J. \& Green, T. C. ,'Economic news and bond prices: Evidence from the US Treasury market., 2001,' Journal of Financial and Quantitative Analysis, VOL.36, NO.4, PP. 523-43.

Chan, Y., Chui, A. C. W. \& Kwok, C. C. Y. 'The impact of salient political and economic news on the trading activity.', 2001, Pacific-Basin Finance Journal, VOL.9, VOL.3, PP.195-217.

Chen, A. H. \& Siems, T. F., 'The effects of terrorism on global capital markets.', 2004, European Journal of Political Economy, VOL.20, NO.2, PP.349-366.

Chuliá, H., Martens, M. \& Dijk, D., 'Asymmetric effects of federal funds target rate changes on S\&P100 stock returns, volatilities and correlations.', 2010, Journal of Banking \& Finance, VOL.34, NO.4, PP.834-839.

Cornell, B., 'Money supply announcements and interest rates: Another view ', 1983, Journal of Business, VOL.56, NO.1, PP.1-23.

Cutler, D. M., Poterba, J. M., \& Summers, L. H., 'What moves stock prices?', 1998, National Bureau of Economic Research, Working Paper \#2538.

Ederington, L. H. \& Lee, J. H. ,'The short-run dynamics of the price adjustment to new information., 1995,' Journal of Financial and Quantitative Analysis, VOL.30, NO.1, PP.117-134.

Engle, R. F., Lilien, D. M. \& Robins, R. P., 'Estimating time varying risk premia in the term structure: the ARCH-M model.', 1987, Econometrica, VOL.55, NO.2, PP.391-407.

Flannery, M. J. \& Protopapadakis, A. A., 'Macroeconomic factors do influence aggregate stock returns', 2002, Review of Financial Studies, VOL.15, NO.3, PP.751-782.

French, K. R., Schwert, G. W. \& Stambaugh, R. F., 'Expected stock returns and volatility.', 1998, Journal of Financial Economics, VOL.19, NO.1, PP.3-29.

Grossman, J. , 'The" rationality" of money supply expectations and the short-run response of interest rates to monetary surprises.', 1981, Journal of Money, Credit and Banking, VOL.13, NO.4, PP.409-24.

Guidolin, M. \& La Ferrara, E. ,'The economic effects of violent conflict: evidence from asset market reactions.', 2005, Journal of Peace Research, VOL. 47, NO.6, PP. 671-684.

Guidolin, M. \& La Ferrara, E., 'Diamonds are forever, wars are not. Is conflict bad for private firms?', 2006, The American Economic Review, Vol. 97, No. 5, pp. 19781993.

Hardouvelis, G. A., 'Economic news, exchange rates and interest rates.', 1988, Journal of International Money and Finance, VOL.7, NO.1, PP. 23-35.

Harvey, C. R. \& Huang, R. D., 'Public information and fixed income volatility.' 1993, Unpublished paper, Duke University, July.

Ito, H. \& Lee, D., 'Assessing the impact of the September 11 terrorist attacks on US airline demand.' , 2005, Journal of Economics and Business, VOL.57, NO.1, PP.75-95.

Jones, C. M., Lamont, O. \& Lumsdaine, R. L., 'Macroeconomic news and bond market volatility1.', 1998, Journal of Financial Economics, VOL.47, NO.3, PP. 315-37. 
MacKinlay, A. C., 'Event studies in economics and finance.' ,1997, Journal of economic literature, VOL.35, NO.1, PP.13-39.

McQueen, G. \& Roley, V. V., 'Stock prices, news, and business conditions', 1993, Review of Financial Studies, VOL.6, NO.3, PP.683-707.

Nikkinen, J., Omran, M., Sahlstrom, P. \& Aijo, J., 'Global stock market reactions to scheduled US macroeconomic news announcements.', 2006, Global Finance Journal, VOL.17, NO.1, PP.92-104.

Nikkinen, J., Omran, M. M., Sahlström, P. \& Äijö, J., 'Stock returns and volatility following the September 11 attacks: Evidence from 53 equity markets.', 2008, International Review of Financial Analysis, VOL.17, NO.1, PP. 27-46.

Pearce, D. K. \& Roley, V. V., 'Stock prices and economic news.', 1985, National Bureau of economic research Cambridge, Working Paper \# 1296.

Rangel, J. G. , 'Macroeconomic news, announcements, and stock market jump intensity dynamics.' 2011, Journal of Banking \& Finance, VOL.35, NO.5, PP.1263-1276.

Rigobon, R. \& Sack, B., 'The effects of war risk on US financial markets.', 2005, Journal of Banking \& Finance, VOL.29, NO.7, PP.1769-1789.

Roll, R. 'R2', 1989, Journal of Finance', VOL. 43, NO.3, PP.541-566.

Schneider, G. \& Troeger, V. E. 'War and the world economy: Stock market reactions to international conflicts.' 2006, Journal of Conflict Resolution, VOL.50, NO.5, PP. 623-645.

Schwert, G. W. , 'Stock Volatility and the Crash of '87', 1990, Review of Financial Studies, VOL.3, NO.1, PP.77-102.

Schwert, G. W. , 'Why does stock market volatility change over time?', 1989, The Journal of Finance, VOL.44, NO.5, PP. 1115-1153.

Urich, T. \& Wachtel, P., 'Market response to the weekly money supply announcements in the 1970s.' ,1981, The Journal of Finance, VOL.35, NO.5, PP.1063-72.

Wei, J. K. C., Liu, Y. J., Yang, C. C. \& Chaung, G. S., 'Volatility and price change spillover effects across the developed and emerging markets.',1995, PacificBasin Finance Journal, VOL.3, NO.1, PP.113-136.

Wolfers, J. \& Zitzewitz, E.,'Using markets to inform policy: The case of the Iraq war.' , 2009, Economica, VOL.76, NO.302, PP.225-50.

Yue-cheong, C. \& Cjw, K., 'Political risk and stock price volatility: The case of Hong Kong.', 1996, Pacific-Basin Finance Journal, VOL.4, NO.2, PP.259-75. 